\title{
Effectiveness Of Active Learning Method Quiz Team Type On Student Learning Outcomes In Subject Ohm Law In SMA Negeri 1 Pundong
}

\author{
Abu Yazid Raisal ${ }^{1}$, Nanang Suwondo ${ }^{2}$ \\ Universitas Ahmad Dahlan \\ Jl. Dr. Soepomo, SH., Janturan, Warungboto, Umbulharjo, Yogyakarta, Indonesia. \\ abuyazidraisal@gmail.com
}

\begin{abstract}
This study aims to measure the increase in student learning outcomes from cognitive aspects and student activity between active quiz type learning methods and conventional methods. The sampling technique is non-random sampling. Data was collected using the pre-test and post-test for cognitive aspects while the affective aspects used the observation. Analysis of the data used the normality test, homogeneity test, and hypothesis testing. The hypothesis test used is a two-party $t$ test. The results show that $\mathrm{t}_{\text {count }}=7.273>\mathrm{t}_{\text {table }}=2.01$ at a significant level of $5 \%$. It means that there are significant differences for cognitive aspects between learning outcomes using the team quiz type and conventional methods of active learning methods. Overall the team quiz method is more effective for improving student learning outcomes from cognitive aspects, and student activities.
\end{abstract}

Keywords: Active learning, team quizzes, learning outcomes

\section{Introduction}

The teacher is the facilitator in the learning process. Therefore, in the learning process the teacher must be able to use the right methods and media so that learning objectives can be achieved. The teacher must try to carry out the learning process that can stimulate student learning activities as much as possible. One of the efforts made by the teacher to obtain optimal results is to create a learning atmosphere that can actively involve students. Active involvement of students in learning activities will enable these students to develop their potential [1]

The value of learning outcomes is one indicator that can be used to measure the success of one's learning. In the teaching and learning process, there are many factors that influence the achievement of student learning outcomes, both from within the student (internal) and the external environment. Internal factors are related to discipline, response and student motivation. While external factors are the learning environment, learning objectives, creativity in the selection of learning media by educators and learning methods [2].
Based on the results of the interview with Suryani, a physics teacher at Pundong Bantul Public High School 1, most students had difficulty understanding physics subjects. The physics score of students on average is in KKM, not many students get grades above KKM. The teaching method used so far is the conventional method, namely the lecture method. It is expected that the methods that can make students have no difficulty understanding physics lessons so that the learning outcomes obtained are satisfactory.

Appropriate learning methods will produce good learning outcomes, namely methods that can improve student learning outcomes according to their development. One method that can be done is by the team quiz type active learning method. Therefore, researchers conducting research using the team quiz method are expected to produce positive results on student learning outcomes and student activities.

\section{Theory}

Learning is an activity or a process to gain knowledge, improve skills, improve behavior, attitudes, and strengthen personality. In the context of becoming aware or the process of gaining 
knowledge, according to conventional scientific understanding, human contact with nature, termed experience (experience). Experience that occurs repeatedly gives birth to knowledge, or a body of knowledge [3].

Active learning is a learning that invites students to learn actively. When students learn actively, it means that they dominate learning activities. With this they actively use the brain, both to find the main ideas of the lecture material, solve problems, or apply what they have just learned into one problem that exists in real life. With this active learning, students are invited to participate in all learning processes, not only mentally but also physically. In this way students will usually feel a more pleasant atmosphere so that learning outcomes can be maximized [4]. Effective teaching is teaching that provides opportunities for students to learn on their own or do their own activities [5]. One method that can be done is by the team quiz type active learning method.

Team quizzes come from the word "quiz" which means a short oral or written test and "team" which means group or group. Team quiz means short oral or written examinations conducted in groups. Team quizzes can increase student learning responsibilities in a pleasant atmosphere. learning procedures using the type of team quiz are as follows: 1 . The teacher selects a topic that can be presented in three parts. 2. Students are divided into three teams, namely team A, team B, and team C. 3 . The teacher explains the learning scenario. 4 . The teacher presents learning material. 5. The teacher asks team A to prepare a short answer quiz, while teams $\mathrm{B}$ and $\mathrm{C}$ use the time to check their notes. 6 . Team A gives a quiz to team B. If team B cannot answer the question, team $\mathrm{C}$ is given the opportunity to immediately answer it. 7. Team A continues the next question to team member $\mathrm{C}$ and repeat the process. 8. When the quiz is finished, continue with the second part of the lesson and point team B as the quiz leader. 9. After the team completes the exam, continue with the third part and determine team $\mathrm{C}$ as the quiz leader [6].

Learning outcomes can be explained by understanding the two words that make it up, namely "results" and "learning". Understanding the results (product) refers to an acquisition due to an activity or process that results in functional changes in input. Likewise in teaching and learning activities, after experiencing learning students change their behavior compared to before. Learning is done to try to change behavior in individuals who learn. Changes in behavior is the acquisition of learning outcomes [7].

\section{Methodology}

This research included a type of quasiexperimental research. Quasi-experimental research can be interpreted as research that approaches experiments or quasi-experiments. In quasiexperimental research, researchers can divide existing groups without differentiating between controls and groups significantly while still referring to existing natural forms [8]. In this research the data collection techniques used were achievement tests, namely tests used to measure achievement of someone who had learned something. The test method in this study was conducted twice. The first test was conducted to determine the students' initial ability (pre-test), then the final test (post-test) was carried out to determine the level of student understanding after the treatment was carried out.

The population of this study were students of class $\mathrm{X}$ semester 2 of SMA 1 Pundong Bantul with the samples taken were classes $\mathrm{X} 3$ as the experimental class and $\mathrm{X} 2$ as the control class. The number of students in the experimental class was 25 students and the control class was 24 students. The experimental class is taught by the Team Quiz method, while the control class is taught as usual, using conventional methods.

The steps of the research are: (1) conducting a preliminary survey, (2) preparing a plan for implementing learning, student work sheets, and research instruments, (3) conducting research instrument trials, (4) analyzing trial data, (5) giving pre-test in the experimental class and control class students, (6) giving treatment by carrying out active learning with team quiz techniques in the experimental class students, while the control class students carried out conventional learning, (7) giving post-tests to the experimental class and control class , (8) analyzing data and interpreting the results obtained.

The hypothesis in this study are as follows:

$\mathrm{H}_{0}=$ there is no difference in student learning outcomes between using the active learning method team quiz type and conventional learning models

$\mathrm{H}_{1}=$ there are differences in student learning outcomes between using the active learning method team quiz type with conventional learning models

\section{Results and Discussion}

The achievement tests was prepared by the researcher with the help of expert judgment to determine the validity of the test contents. Validity, reliability, level of difficulty, and different power of 
test questions were obtained through research instrument trials. After going through the trial process, 20 physics test results were obtained. Test data were analyzed descriptively to find out the results of student physics learning. The difference in the average score of the learning outcomes of the experimental class and control class students was analyzed using the t-test. Before testing the hypothesis, the normality test and homogeneity test are carried out first. Normalization test aims to determine whether the data obtained is normally distributed or not. The homogeneity test was conducted to determine whether the two samples studied had the same variance level or not.

Table 1. Normality test results for data distribution pre-test and

\begin{tabular}{lccccc}
\multicolumn{6}{c}{ post-test } \\
\hline $\begin{array}{c}\text { Test } \\
\text { group }\end{array}$ & $\begin{array}{c}\text { Significan } \\
\text { t level }\end{array}$ & $\chi_{\text {count }}^{2}$ & $\chi_{\text {table }}^{2}$ & $\mathrm{dk}$ & $\begin{array}{c}\text { Distributi } \\
\text { on }\end{array}$ \\
\hline $\begin{array}{l}\text { pre-test } \\
\text { expe }\end{array}$ & $5 \%$ & 2,15 & 7,81 & 3 & Normal \\
\hline $\begin{array}{l}\text { pre-test } \\
\text { control }\end{array}$ & $5 \%$ & 5,46 & 7,81 & 3 & Normal \\
\hline $\begin{array}{l}\text { post-test } \\
\text { expe }\end{array}$ & $5 \%$ & 3,58 & 7,81 & 3 & Normal \\
\hline $\begin{array}{l}\text { post-test } \\
\text { control }\end{array}$ & $5 \%$ & 7,73 & 7,81 & 3 & Normal \\
\hline
\end{tabular}

Table 1 shows normality test results for data distribution pre-test and post-test. From the calculation of the normality test the value of $\chi_{\text {count }}^{2}$ pre-test for the group of students taught by the quiz type active learning method $=2.15$ with $\chi_{\text {table }}^{2}=$ 7.81 at the significant level of $5 \%$ and $\mathrm{dk}=3$. Whereas the value $\chi_{\text {count }}^{2}$ pre-tests for groups of students taught with conventional methods $=5.46$ with $\chi_{\text {table }}^{2}=7.81$ at a significant level of $5 \%$ and $\mathrm{dk}$ $=3$. The data is in accordance with the provisions, then the data is normally distributed.

From the calculation of the normality test obtained the value of $\chi_{\text {count }}^{2}$ post-test for the group of students taught by the team quiz type active learning method $=3.58$ with $\chi_{\text {table }}^{2}=7.81$ at a significant level of $5 \%$ and $\mathrm{dk}=3$. Whereas the value $\chi_{\text {count }}^{2}$ post-tests for groups of students taught by conventional methods $=7.73$ with $\chi_{\text {table }}^{2}=7.81$ at a significant level of 5\% and $\mathrm{dk}=3$. The data is in accordance with the provisions, then the data is normally distributed.
Table 2. Homogeneity test results for data distribution pre-test

\begin{tabular}{lccccl}
\multicolumn{5}{c}{ and post-test } \\
\hline $\begin{array}{l}\text { Test } \\
\text { group }\end{array}$ & $\begin{array}{l}\text { Significant } \\
\text { level }\end{array}$ & $\chi_{\text {count }}^{2}$ & $\chi_{\text {tabel }}^{2}$ & Dk & Distribution \\
\hline $\begin{array}{l}\text { Pre- } \\
\text { test }\end{array}$ & $5 \%$ & 4,23 & 7,81 & 3 & Homogen \\
\hline $\begin{array}{l}\text { Post- } \\
\text { test }\end{array}$ & $5 \%$ & 0,05 & 7,81 & 3 & Homogen \\
\hline
\end{tabular}

Table 2 shows Homogeneity test results for data distribution pre-test and post-test. The homogeneity test of the data in this study uses the Barlett test with the provision of homogeneity if $\chi_{\text {count }}^{2} \leq \chi_{\text {table }}^{2}$. It can be seen that the value of $\chi_{\text {count }}^{2}$ lower then $\chi_{\text {table }}^{2}$ for data distribution pre-test and post-test with significant level $5 \%$ and $\mathrm{dk}=3$. It can be concluded that the sample comes from a homogeneous population.

Based on the results of the normality test and the homogeneity test of the learning outcomes of the experimental and control class students, it can be determined that the different test scores on the average student learning outcomes can use the t-test (with the formula for normal and homogeneous data). The t-test was used to determine the differences in student learning outcomes that were significant between the experimental class and the control class.

Table 3. Summary of the results of the t-test

\begin{tabular}{lllll}
\hline $\mathrm{dk}$ & Significant level & $t_{\text {count }}$ & $t_{\text {table }}$ & Conclusion \\
\hline 47 & $5 \%$ & 7,273 & 2,01 & $\mathrm{H}_{0}$ rejected \\
\hline
\end{tabular}

Table 3 shows summary of the results of the t-test. From the table 3, it can be seen that the value of $\mathrm{t}_{\text {count }}=7.273>\mathrm{t}_{\text {table }}=2.01$ from the distribution table $\mathrm{t}$ with a significant level of $5 \%$ and $\mathrm{dk}=47$ obtained the price $\mathrm{t}=2.01$ so that $\mathrm{H}_{0}$ is rejected and $\mathrm{H}_{1}$ is accepted namely "there are differences in student learning outcomes between using team quiz learning model with conventional learning models ".

The Quiz Team encourages students to be active in the lesson so that students more easily understand the material provided. Students are encouraged to create and solve problems themselves. Unlike the conventional method, students only listen to what is taught by the teacher without actively participating in learning. Students just sit and pay attention to the teacher explaining the material being taught. So that it is possible for many students who do not know clearly how to solve the problem. 


\section{Conclusion}

There is an increase between student learning outcomes using team and conventional quiz methods. This can be proven by the results of the ttest which shows that $t_{\text {count }}>t_{\text {table }}$ is $7.273>2.01$. The Quiz Team encourages students to be active in the lesson so that students more easily understand the material provided. Students are encouraged to create and solve problems themselves.

\section{Reference}

[1] Usmeldi, Efektivitas Pembelajaran Aktif Dengan Teknik Kuis Tim Pada Mata Pelajaran Fisika di SMKN 1 Bukittinggi, Prosiding Seminar Nasional Fisika, 2012, pp.131-136.

[2] Maisaroh and Rostrieningsih, Peningkatan Hasil Belajar Siswa dengan Menggunakan Metode Pembelajaran Active Learning Tipe Quiz Team pada Mata Pelajaran Keterampilan Dasar Komunikasi di SMK Negeri 1 Bogor, Jurnal Ekonomi \& Pendidikan, 2010,pp. 157-172.

[3] Suyono, and Hariyanto, Belajar dan Pembelajaran. Bandung: PT. Remaja Rosdakarya, 2011.

[4] H. Zaini, B. Munthe, and S. A Aryani, Strategi Pembelajaran Aktif, Yogyakarta: Institut Agama Islam Negeri Yogyakarta. 2007

[5] O. Hamalik, Proses Belajar Mengajar, Jakarta, Bumi Aksara, 2012.

[6] M. L. Silberman, Active Learning: 101 Cara Belajar Siswa Aktif, Bandung: Nusamedia, 2009.

[7] Purwanto, Evaluasi Hasil Belajar, Yogyakarta, Pustaka Pelajar, 2013.

[8] Sukardi, Metodologi Penelitian Pendidikan, Jakarta, Bumi Aksara, 2003. 